\title{
Morphology Of Legends Folktale Of The Minangkabau Boys In West Sumatra Who Was Rebellious To His Mother
}

\author{
Hasanuddin WS ${ }^{1}$, Emidar ${ }^{2}$, Zulfadhli $^{3}$ \\ \{hasanuddinws@pps.unp.ac.id ${ }^{1}$, emidarfahmi@yahoo.co.id², zulfadli@fbs.unp.ac.id ${ }^{3}$ \} \\ ${ }^{1,2,3}$ Fakultas Bahasa dan Seni Universitas Negeri Padang, Indonesia
}

\begin{abstract}
This research article contains a discussion about the morphology of the legends folktale of the Minangkabau boys in West Sumatra who was rebellious to his mother. This research is a descriptive qualitative study. Morphological data was obtained through a search of the structure of the motives and role functions of the four legends folktale of the Minangkabau boys in West Sumatra who was rebellious to his mother. The data sources of this study are legendary folktales (1) Malin Kundang and (2) Si Boko represents the coastal area of West Sumatra, (3) Batu Lengong, and (3) Bukit Talio representing the mainland area of West Sumatra. This study of the legends folktale of the Minangkabau boys in West Sumatra who was rebellious to his mother uses the theory of structural studies as used by Proop (1967, 1984), Greimas (1972), Scoles (1974), Rusyana (2000), and Hasanuddin WS (2018, 2019). The theory used assumes that the motives in the structure of folktale are the main thing because of the motives that make up the theme and explain the possibility of spreading the folktale to other regions. West Sumatra as the main residence area of the Minangkabau people has many legends folktale of rebellious children, both of rebellion boys and girls. The motive of the story of a rebellious boys to his mother is important to know and compare. Based on the research findings, the motifs of legends folktale of rebellious boys to their mothers have the same motive for the perpetrators' functions. The motives of the perpetrator's function on the legends folktale of the Minangkabau boys who was rebellious to his mother were (1) Initial situation: (a) living as an only child, (b) living only with mother, (c) living in very simple/ poor conditions (d ) want to change destiny for the better; (2) Transformation situation: (e) migrate following merchants and business people, (f) work hard and economically, (g) become rich and get married to women from families/ wealthy, (h) return to their hometown to meet their mothers; (3) Final situation: (i) meeting with an elderly and poor mother, (j) refusing to acknowledge her old and poor mother because she is ashamed of his wife, (k) condemned by her mother; (l) changes shape to stone due to the curse of his mother. The morphology of the legends folktale the Minangkabau boys in West Sumatra who were rebellious to their mother from the West Sumatra coastal region is more complete and intact than the legends folktale of the West Sumatra from mainland region.
\end{abstract}

Keywords: morphology, legendary folktale, rebellious boys, West Sumatra, Minangkabau people 


\section{Introduction}

Legendary folklore, especially folktale, local legends is part of oral literature that is considered and trusted by the people who own it as something that really happened or happened. As a matter of truth, local legends folktale has an important position. Human life, and by itself relations between people, are controlled by beliefs. If it grows and develops, beliefs or beliefs are accepted as a truth. Public belief in something may well cross the line of general logic, but such beliefs according to Barthes (2003: 124) cannot be blamed. The thing that must be considered from the community's belief is not the issue of true or false beliefs, but the extent to which these beliefs function in fulfilling the social functions of the community's life.

Minangkabau people or people are one of the strongest ethnic groups in Indonesia. The Minangkabau identity has contributed to the form of Indonesia's national culture, including language, art, culinary, and various other aspects of tradition. People who are able to contribute their culture are people who are strong, solid, and proud of their identity.

In terms of folklore, local legends, people or Minangkabau people have stories of local legends about rebellious childrens which are very legendary and are known in almost all regions of Indonesia, even in several Southeast Asian countries, namely the story of the legend of the rebellious child Malin Kundang. Many things caused why the legends folktale of the legend of Malin Kundang became famous and widely known, even adapted by people outside the Minangkabau people. This is also evidence of the contribution or contribution of Minangkabau people in terms of culture.

Indeed, the Minangkabau people in West Sumatra not only have folktale about a Malin Kundang as a rebellious boy to his mother, there are still others, even many. In addition, the Minangkabau people in West Sumatra also have many folktale of local legends that are rebellious daughters to their mothers. Folktale about another son besides Malin Kundang who was a disobedient mother, among others, was the legends folktale of Batu Kutu (Surantiah, Pesisir Selatan), Batu Tagak (Sungai Lareh, Kota Padang), Batu Lengong (Lembah Gumanti, Solok), Si Boko (Sungai Pisang, Kota Padang), Batu Galeh (Sulikaie, Solok), Bujang Jibun (Surantiah, Pesisir Selatan), Bukik Talio (Taram, Lima Puluh Kota), and Nankodo Bincik (Solok). Whereas local folklore stories about daughters who were rebellious to their mothers included Awang Tingkuluak (Sungai Sariak, Padangpariaman), Batu Menangis (Sungai Tarab, Tanah Datar), Batu Puti Bayang (Nagari Api-api Bayang, Pesisir Selatan), Batu Menagis (Ngalau, Payakumbuh), and Batu Bangkai (Pauah Duo, Solok Selatan). Thus, the reality of the many stories about Minangkabau children who are rebellious to their mothers, both boys and girls is a unique and very interesting phenomenon to be studied further from various aspects. The study in this study focused only on the structural study of the story, about its morphology, and only on the sons of the Minangkabau in West Sumatra who were rebellious to their mothers.

Folktale (local legends) about the Minangkabau boys were rebellious to his mother as the object of research are legendary folktale (1) Malin Kundang, (2) Si Boko, (3) Batu Lengong, and (4) Bukik Talio. Selection considerations are based on the representation of the story with the background story of the coastal area of West Sumatra (coast), and the background story of the area not the coast (mountains). Local legend folktale Malin Kundang and Si Boko represent the story with the background story of the coastal area (Kota Padang and Pesisir Selatan), while the story with the background story is not coastal (mountains) represented by folktales of Batu Lengong and Bukik Talio (Solok and Lima Puluh Kota). 
The study of the four folktale stories of local legends is focused on structural studies, especially on story morphology. As Proop and Greimas's attention, the study of four local legendary folktale of Minangkabau boys in West Sumatra who were rebellious to their mothers did not focus on the study of the intrinsic elements of literary texts, but instead focused on the most important narrative motives, namely actions and roles actor (story character). Proop (1987) and Greimas (1972) give equal attention in establishing the morphology of folklore, namely giving emphasis to actions and not to the perpetrators of the story. This is also the case with this study.

By knowing the morphology of the functional structure of local legends folktale text of Minangkabau boys who are rebellious to their mothers, as previously explained, a number of things can be concluded, for example about the philosophy of life, concepts, behavior, perceptions, and problems about Minangkabau people. Research to form the morphology of the local legends folktale of the Minangkabau boys in West Sumatra were rebelliouys to his mother is one of the stages to be able to answer questions about a number of formulations of the social behavior of Minangkabau people. This formulation can be seen as the basic values that have "cemented" the Minangkabau ethnic community into a strong ethnic group and exist in this archipelago.

\section{Literature Review}

The study of the morphology of the local legends folktale of Minangkabau boys in West Sumatra were rebellious to his mother was carried out as a study of narrative oral literature. This was done by Proop (1928, 1967, and 1987) and Greimas (1972). Scholes (1974) on the basis of Proop's study and Greimas conducted a study of stories in drama texts with the same principle. Thus, the study of the category of local legend of Minangkabau boys in West Sumatra who were rebellious to their mother was the foundation of the study of structure.

Propp (1967 and 1984) was the first structuralist figure to carry out a thorough study of the narrative structure while giving new meaning to the fibula dichotomy and sjuzet. Proop (1967) concluded that the narrative story of one hundred Russian folklore he collected had the same structure. What he means is, in the folklore of the perpetrators and their characteristics can change, but the actions and functions are the same, do not change. Proop views sujzet as a theme not a plot as understood by formalists. According to Proop (1987) motives are important elements because motives form the theme. The motives in the structure of folklore can be divided into three, namely (i) perpetrators, (ii) actions, and (iii) victims.

Greimas (1972) conducted a narrative analysis of story texts. The study includes two stages of structure, namely the phyisical structure and inner structure. Greimas naratology is a combination of the Levi-Strauss paradigmatic model with the Proop syntagmatic model. Compared to Proop, the object of Greimas' study is not limited to folk tales, but is extended to myths. Greimas and Proop's similarity is to emphasize actions and not the actors of the story. Greimas argues that the concrete is an action which then forms the actor as a false subject (see also Teeuw (1984), Junus (1993), and Hasanuddin WS (2018; 2019).

From the various reference references as discussed above, the study of the morphology of the local legens folktale of the Minangkabau boys in West Sumatra who were rebellious to his mother in this discussion looks special, that is, on the object of his study. The object of the study focused only on local legend folktale of Minangkabau boys in West Sumatra who were rebellious to their mothers, and not daughters, and not outside the administrative area of West Sumatra. The results of this study, in addition to of course producing documentation of local legendary folktale of Minangkabau boys in West Sumatra who were rebellious to their 
mothers, also resulted in classification or categorization, especially the morphological aspects. On the other hand, in terms of its relation to the development of the world of tourism, the results of documentation and morphological categorization of folklore will enable it to be used to increase the attractiveness of tourism to areas in West Sumatra. Tourists who visit West Sumatra not only enjoy nature and culinary, but also can hear and know the folklore of local legends related to the area they visit.

\section{Methods}

The research that forms the basis of the preparation of this article is qualitative research, research carried out by not using numbers and statistical data processing, but prioritizing researchers' appreciation of interactions between concepts that are being studied empirically. A study carried out with the intention of understanding the phenomenon of what is experienced by the subject of research such as behavior, perception, motivation, action, holistically, with a specific natural context, and by utilizing scientific methods.

This research is a study that produces descriptive data in the form of written or oral words from people and observable behavior, depending on observations in humans, both in the region and in its terminology. This research prioritizes the natural setting and is carried out to present the social world, and its perspective in the world in terms of concepts, behaviors, perceptions, and problems concerning the human being studied.

The data of this study are morphological data on the stories of oral literature from local legends folktale of Minangkabau boys in West Sumatra who are rebellious to their mothers. Data collection is carried out in two stages. The first stage is the inventory stage through literature studies (document analysis) and recording of oral literature of legend folktale of Minangkabau people in West Sumatra. Data that is told directly by the informant is recorded using a recording device. Recordings are transcribed into written form. The result of transcription (literacy) is then transliterated (transitional) from the Minangkabau language into Indonesian. The text of the story of the transliteration results is further examined by the functional structure of the morphology using theory as explained earlier. The second stage is collecting data about the storytelling environment, including the views and philosophy of life, as well as the life values of the people who speak the story of local legend related to the oral literature of the Minangkabau legend in West Sumatra. Data about the storytelling environment was collected through recording techniques, observations, and interviews.

\section{Results and Discussion}

\section{a. Functional Structure}

The findings of this study show that the of local legends folktale of Minangkabau boys in West Sumatra who were rebellious to their mother, based on functional structures, can be formulated in twelve function functions arranged in three situations, namely the initial situation, the transformation situation, and the final situation. In the initial situation there were four functions of the perpetrator, namely (a) living as an only child, (b) living only with the mother, (c) living in a very simple / poor condition, (d) wanting to change the destiny for the better. In the transformation situation there are four functions of the perpetrator, namely (e) migrating to follow merchants and business people, (f) working hard and frugally, (g) becoming rich and getting married to women from families / wealthy, $(\mathrm{h})$ returning to their hometown to meet her mother. In the final situation there are four functions of the perpetrator, 
namely (i) meeting with an elderly mother who is still poor, (j) refusing to recognize her old and poor mother because she is ashamed of his wife, (k) condemned by his mother; (l) changes shape to stone due to the curse of his mother.

The four folktale that became the object of study can be explained as follows. Legend folktale of Malin Kundang in the Early Situation, told Malin Kundang is the only child (a) who no longer has a father and only lives with his mother (b), they both live in a state of lack or poverty because their mother only works as a wood collector burn in the forest around Air Manis Beach where they live, however Malin Kundang is very loved by his mother, whereever goes Malin Kundang is always carried (carrying in Minangkabau language called kundang) by his mother, that's why he is called Si Malin Kundang, Malin is always invited or held by his mother (c), aware of their poverty, Malin Kundang aspires to be rich and can please his mother's life (d). In the Situation of Transformation, it was told to stop the ark of a wealthy merchant on Air Manis Beach who wanted to take clean water for drinking supplies that had run out, Malin Kundang asked his mother for permission to sail and work for the rich merchant, his mother allowed and the rich merchant was willing to accept Malin Kundang to come with him (e), Malin Kundang worked earnestly, diligently, disciplined, lived frugally so that the rich merchants were very pleased with Malin Kundang (f), because of his perseverance Malin Kundang became a successful merchant as well and living well in the wanderings of people and can marry a beautiful merchant's daughter $(\mathrm{g})$, after having a family Malin remembered his mother in his hometown, on Air Manis Beach, then sailed with his wife and entourage to his hometown to meet his mother (h). In the Final Situation, it was said that Malin Kundang's ark anchored on Air Manis Beach and he met his mother, but he was shocked because his mother remained poor and looked very old and dingy (i), such circumstances caused Malin Kundang to be ashamed of his wife do not acknowledge that the poor, old, and shabby woman is his biological mother (j), his mother feels very sad and disappointed at Malin Kundang's actions, then prays to God, if it is true Malin Kundang is his biological child who has drunk his milk, then curse he became a stone (k), suddenly a rainstorm came, lightning merged and merged, Malin Kundang along with his ark crashed to the shore of Air Manis Beach, Padang City and turned to stone (1).

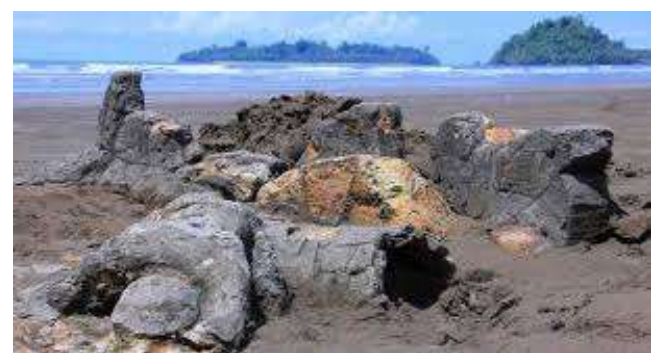

Picture 1. Malin Kundang Stone on Air Manis Beach, Padang West Sumatra

The Si Boko Legend folktale in the Early Situation, told that Si Boko is said to be the only child (a) who no longer has a father and only lives with his mother (b), they both live in a state of poverty or poverty because of their mother and are only able to farm simple on the hillside around where they live on the Sungai Pisang Bungus (c), aware of their poverty, Si Boko aspires to be rich and be able to please his mother's life by (d). In In the Situation of Transformation, Si Boko went to leave his hometown to look for fortune (e), Si Boko through 
his hard work to become a successful and wealthy overseas (f), because Si Boko's wealth had many men and had wives who beautiful $(\mathrm{g})$, Si Boko returned home to his village on the Sungai Pisang Bungus on a boat he owned (h). In the Final Situation, Si Boko was reunited with his mother, but he was surprised because his mother remained poor and looked very old and dingy (i), such circumstances caused Si Boko to refuse to admit that the poor, old, and dirty woman was his biological mother $(\mathrm{j})$, his mother felt very sad and disappointed at $\mathrm{Si}$ Boko's action and then swore and condemned Si Boko in Spilling (k), Si Boko and all of his ships became rocks in the Sungai Pisang Bungus area of Padang City (l).

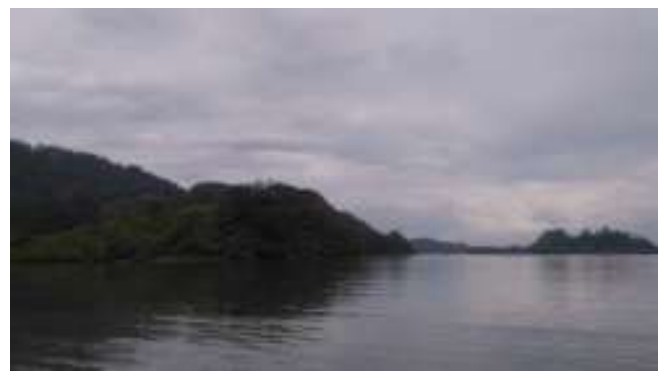

Figure 2. Si Boko Stone on the Sungai Pisang Bungus in Padang West Sumatra

The Batu Lengong or Bujang lengong Legend Story in the Early Situation, told there was a family that only had a son (a) the boy lived alone with his mother (b), they both lived in a state of lack or poverty because of his mother and he only able to earn a living from the forest around them in the Lembah Gumanti (c), this boy used to be called Bujang, likes to hunt into the forest with his basket, pole and $\operatorname{dog}(\mathrm{d})$ In the Transformasi Situation, told Bujang to go abroad to leave his hometown to look for fortune of fate by trading cloth (e), Through the hard work of trading cloth he became a rich man (f), there was no function of the perpetrators of this stage (g), Bujang returned to his village in the Lembah Gumanti (h). In the Final Situation, it was told that Bujang was reunited with his mother, but he was surprised because his mother remained poor and looked very old and dingy (i), this condition caused the Bujang to refuse to admit that the woman was poor, old, and dirty. refuse the food the mother has provided and then go to the forest to do her pleasure, which is hunting with a basket, pole and a dog (j), her mother feels very sad and disappointed at the act of the Blessed One and curses the child (k), the bachelor upon arrival in Bukit Lembang Pinjaro Lembah Gumanti hearing the curse of his mother, he turned (Minangkaba language call malengong) and when he turned it over, his pole, his basket, his dog, and himself turned into stone, known as the stone Bujang Lengong (1).

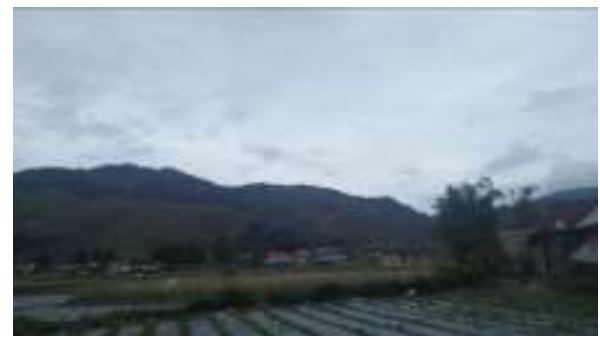

Figure 3. Bukit Lembang Pinjaro Lembah Gumanti Bujang Lengong Hunting Place and turned into stone 
Bukit Talio Legend Story in the Early Situation, said to be told of a boy from a family living in Mungka (a) living with his mother (b), their family lived a simple life as a farming family (c), there was no function of the perpetrator at this stage (d). In the Transformasi Situation, the boy went to the mosque, which was quite far from his house for Friday prayers (e), the mother of the boy told him not to eat the bananas at home because the banana was a banana he had long desired (f), coming home from Friday prayers this boy felt tired and very hungry (g), this boy forgot to order his mother, he ate the banana (h). In the Final Situation, told the mother, the boy learned that his banana had been eaten up by his son (i), the mother scolded and chased her running son and hid in the Batu Bulek Mungka and refused to apologize and disobeyed the mother's instructions to go home, but continued to climb Batu Bulek to its peak (j), his mother felt very sad and disappointed at his son's actions and then swore and cursed his child $(\mathrm{k})$ When that big lightning came, the large lightning grabbed the child so that the Batu Bulek split into nine the part and child who is not obedient to the mother changes to stone (1).

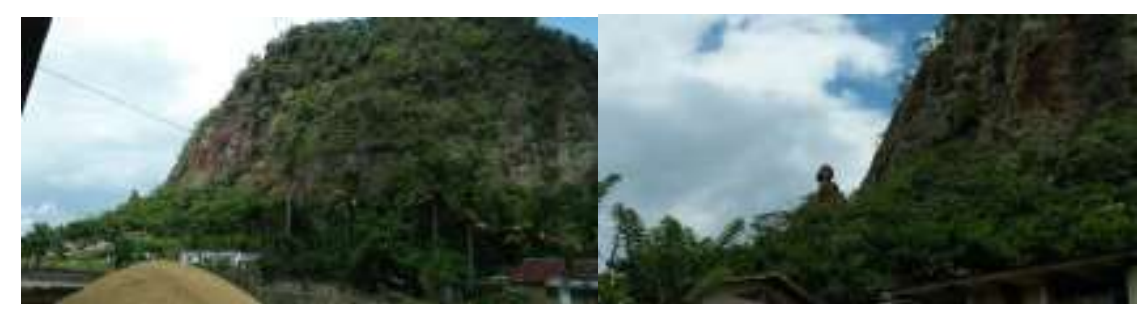

Figure 4. Batu Bulek in Mungka

Figure 5. Batu Bukit Talio in Mungka district

Based on the explanation of the functional structure based on the initial situation, the transformation situation, and the final situation above, the morphology of the local legend folktale of the Minangkabau boys who were rebellious to their mother can be seen in the following table.

Table 1. Functional Model of Legends Folktale Boys The Minangkabau Boys in West Sumatra who was Rebellious to his mother

\begin{tabular}{|c|c|c|c|c|c|c|c|c|c|c|c|c|c|}
\hline \multirow[t]{3}{*}{ Num. } & \multirow{3}{*}{$\begin{array}{l}\text { Titles of the } \\
\text { Legends } \\
\text { Folktale }\end{array}$} & \multicolumn{12}{|c|}{ Function character } \\
\hline & & \multicolumn{4}{|c|}{$\begin{array}{l}\text { Initial } \\
\text { situation }\end{array}$} & \multicolumn{4}{|c|}{$\begin{array}{l}\text { Transformation } \\
\text { Situation }\end{array}$} & \multicolumn{4}{|c|}{$\begin{array}{l}\text { Final } \\
\text { Situation }\end{array}$} \\
\hline & & $\mathbf{a}$ & $\mathbf{b}$ & c & d & $\mathbf{e}$ & f & g & h & i & $\mathbf{j}$ & $\mathbf{k}$ & 1 \\
\hline 1. & Malin Kundang & $\sqrt{ }$ & $\sqrt{ }$ & $\sqrt{ }$ & $\sqrt{ }$ & $\sqrt{ }$ & $\sqrt{ }$ & $\sqrt{ }$ & $\sqrt{ }$ & $\sqrt{ }$ & $\sqrt{ }$ & $\sqrt{ }$ & $\sqrt{ }$ \\
\hline 2. & Si Boko & $\sqrt{ }$ & $\sqrt{ }$ & $\sqrt{ }$ & $\sqrt{ }$ & $\sqrt{ }$ & $\sqrt{ }$ & $\sqrt{ }$ & $\sqrt{ }$ & $\sqrt{ }$ & $\sqrt{ }$ & $\sqrt{ }$ & $\sqrt{ }$ \\
\hline 3. & Batu Lengong & $\sqrt{ }$ & $\sqrt{ }$ & $\sqrt{ }$ & - & $\sqrt{ }$ & $\sqrt{ }$ & - & $\sqrt{ }$ & $\sqrt{ }$ & $\sqrt{ }$ & $\sqrt{ }$ & $\sqrt{ }$ \\
\hline 4. & Bukik Talio & $\sqrt{ }$ & $\sqrt{ }$ & $\sqrt{ }$ & $\sqrt{ }$ & $\sqrt{ }$ & $\sqrt{ }$ & - & - & - & $\sqrt{ }$ & $\sqrt{ }$ & $\sqrt{ }$ \\
\hline
\end{tabular}

Based on these findings, the morphological functional structure of the local legend folktale of the Minangkabau boy in West Sumatra who were rebellious to their mother from the coastal area of West Sumatra has the same and complete morphology. Whereas stories originating 
from the mainland (mountains) region of West Sumatra have a simpler function of functional structure compared to stories originating from coastal areas. Another thing, between the two stories originating from the mainland (mountains), turned out to have a relatively diverse functional structure.

\section{b. Actor Motives}

Folk stories of local legends about the Minangkabau boys in West Sumatra who were rebellious to their mothers were numerous and varied. This is also consistent with the allegations of folklore researchers, such as Proop (1967, 1987) Greimas (1929), Dundes (1971), Brunvand (1975), Danandjaja (1984, 2003), and Koentjaraningrat (2009), that the number legendary folklore in every culture is far more than myth and fairy tales. This is because legends folktale, especially local legend, has an unlimited number of basic types. Local legend folktale will continue to be produced so that it will always increase in number compared to legendary folklore that can wander from one area to another (migratory legends).

The four local legendary folklore about the Minangkabau boys in West Sumatra who were rebellioius to their mother, the object of this research came from two different regions, namely from the coastal area of West Sumatra and from the mainland (mountainous) region of West Sumatra. There are identical perpetrators' motives and there are also motives of different actors between the two different regional stories. To find out how the similarities and differences in the motives of the local legend folktale about the sons of Minagkabau boys in West Sumatra who were rebellious to their mother, see the following explanation.

The motives of the existing and (identical) actors in the functional structure of local legend about the Minangkabauboys in West Sumatra who were rebellious to their mothers from the two regions are as follows, namely (1) A rebellious boy to his mother is an only child. He has no brother; (2) A rebellious boy to his mother lives and is raised only by his mother (single parent); (3) A rebellious boy to his mother comes alive in poor because the mother of an ungodly boy does not have broad access to economic resources; (4) A son who is rebellious to his mother before the condemnation of committing an act which is not pleasing to his mother; and (5) A son of disobedience to his mother, completely transformed into stone after being cursed by their mother.

The motives of different actors in the functional structure of local legend about the Minangkabau boys in West Sumatra who were rebellious to their mothers from the two regions are as follows, namely (1) Boys from disobedient coastal areas to their mothers must leave their mothers to wander to get success in the economic field (get rich) so that they can help and please their mothers; (2) Boys from lawless coastal areas to their mothers returned home after success and became rich to meet their mothers, but later when they met, they were ashamed to admit their mothers because their mothers were poor, looked very old, and were dirty. This is what makes their mother disappointed, sad, and feels abused; (3) Boys from the lawless mountainous regions of their mothers do not (must) leave their mothers to wander to gain success in the economic field (to become rich) so that they can help and please their mothers; (4) The boys of a rebellious mountain region to his mother is not too disturbed by the condition of poverty, the desire to improve his destiny by wandering out so that things become rich and refusing to admit to having a poor mother is not the cause of rebellion, but by the behavior of those who ignore orders and prohibitions from their mothers.

Based on the explanation of the similarities and differences in the functional structure of the motives of the perpetrators of the Minangkabau boys in West Sumatra who were rebellious 
to their mothers from the coastal and mainland areas of West Sumatra can be seen in the following table.

Table 2. The Similarities and Differences in the Motivation of Folk Stories of Local Legends of Men of the Minangkabau Man of Durhaka to His Mother from the Coastal and Mountainous Regions of West Sumatra

\begin{tabular}{|c|c|c|c|c|}
\hline \multirow[t]{2}{*}{ Num. } & \multicolumn{2}{|c|}{$\begin{array}{l}\text { The area of origin of the } \\
\text { Legends Folktale }\end{array}$} & \multicolumn{2}{|c|}{ Actor Motives } \\
\hline & Coastal & Mountains & Equation & Difference \\
\hline \multirow[t]{5}{*}{1.} & \multirow[t]{5}{*}{$\begin{array}{l}\text { Malin } \\
\text { Kundang } \\
\text { and } \quad \mathrm{Si} \\
\text { Boko }\end{array}$} & \multirow[t]{5}{*}{$\begin{array}{l}\text { Batu } \\
\text { Lengong and } \\
\text { Bukit Talio }\end{array}$} & $\begin{array}{l}\text { A rebellious boy to } \\
\text { his mother is an } \\
\text { only child. He } \\
\text { doesn't have } \\
\text { another brother }\end{array}$ & \\
\hline & & & $\begin{array}{l}\text { A rebellious boy to } \\
\text { his mother lives and } \\
\text { is raised only by his } \\
\text { mother (single } \\
\text { parent) }\end{array}$ & \\
\hline & & & $\begin{array}{l}\text { The rebellious boy } \\
\text { of his mother came } \\
\text { to live in } \\
\text { kemiskimnan } \\
\text { because the mother } \\
\text { of the lawless boy } \\
\text { did not have broad } \\
\text { access to economic } \\
\text { resources }\end{array}$ & \\
\hline & & & $\begin{array}{l}\text { A son who is } \\
\text { rebellious to his } \\
\text { mother before the } \\
\text { condemnation of } \\
\text { committing an act } \\
\text { that does not please } \\
\text { their mother }\end{array}$ & \\
\hline & & & $\begin{array}{l}\text { A rebellious boy to } \\
\text { his mother, all } \\
\text { turned into stone } \\
\text { after being cursed } \\
\text { by their mother. }\end{array}$ & \\
\hline
\end{tabular}




\begin{tabular}{|c|c|c|c|}
\hline & \multirow[t]{3}{*}{$\begin{array}{l}\text { Malin } \\
\text { Kundang } \\
\text { and } \\
\text { Boko }\end{array}$} & \multirow[t]{3}{*}{$\begin{array}{l}\text { Batu } \\
\text { Lengong and } \\
\text { Bukit Talio }\end{array}$} & $\begin{array}{l}\text { Boys from lawless } \\
\text { coastal areas to } \\
\text { their mothers must } \\
\text { leave their mothers } \\
\text { to wander to get } \\
\text { success in the } \\
\text { economic field (get } \\
\text { rich) so they can } \\
\text { help and please } \\
\text { their mothers }\end{array}$ \\
\hline & & & $\begin{array}{l}\text { Boys from lawless } \\
\text { coastal areas to } \\
\text { their mothers } \\
\text { returned home after } \\
\text { success and became } \\
\text { rich to meet their } \\
\text { mothers, but later } \\
\text { when they met, } \\
\text { they were ashamed } \\
\text { to admit their } \\
\text { mothers because } \\
\text { their mothers were } \\
\text { poor, looked very } \\
\text { old, and were dirty. } \\
\text { This is what makes } \\
\text { their mothers } \\
\text { disappointed, sad, } \\
\text { and feel harassed } \\
\text { Boys from } \\
\text { disobedient } \\
\text { mountain areas to } \\
\text { their mothers do } \\
\text { not (have to) leave } \\
\text { their mothers to } \\
\text { wander to get } \\
\text { success in the } \\
\text { economic field (get } \\
\text { rich) so they can } \\
\text { help and please } \\
\text { their mothers }\end{array}$ \\
\hline & & & $\begin{array}{l}\text { Boys from the } \\
\text { lawless } \\
\text { mountainous } \\
\text { regions of their } \\
\text { mothers are not too } \\
\text { disturbed by the }\end{array}$ \\
\hline
\end{tabular}




\begin{tabular}{|l|l|l|}
\hline & & $\begin{array}{l}\text { conditions of } \\
\text { poverty but they } \\
\text { take action not to } \\
\text { obey orders and } \\
\text { prohibitions from } \\
\text { their mothers so } \\
\text { that their mothers } \\
\text { are disappointed, } \\
\text { sad, and feel } \\
\text { harassed. }\end{array}$ \\
\hline
\end{tabular}

The phenomenon of local legend folktale about the Minangkabau boys in West Sumatra who were rebellious to their mother continued to live and dominate the folklore of the legend of Minangkabau people in West Sumatra, must be given attention in the investigation. The number of stories is very large, even in one area, for example, Mungka in Lima Puluh Kota Regency found more than one story of a child who was rebellious to his mother, both boys and girls. The interesting thing about this as an initial prediction, as the results of the study of functional structures carried out in this study appear to be the functional structure and motives of different actors from two different regions. It can be assumed that there are also differences in the functional structure and motives of the offender.

Based on the preliminary study, there was a difference in functional structure between the sons and daughters. The motives and characteristics of male and female child offenders appear to be different. This is unique and requires further research. In addition to the problem of functional structure, matters relating to the aspect of wandering (migration) the story of these rebels, it seems that there is an archetype that can be assumed that the odyssey of local legendary stories about lawyers in West Sumatra is the odyssey of monogenesis, ie there is one discovery in one area Minangkabau in West Sumatra followed a process of diffusion into other Minangkabau areas in West Sumatra, even outside of the Minangkabau region of West Sumatra. This allegation must be answered through separate research.

Therefore. the research findings in the form of morphology from the legends folktale of the Minangkabau boys in West Sumatra who were rebellion to their mother opened up another greater possibility for further research on legendary folklore related to motherhood and possibly related to other folktales, such as myths and fables Minangkabau people in West Sumatra. According to Hadi (2002), Navis (2002), Goodenough (1981) and Sedyawati (2007) it will be done earlier because the authenticity of the story will be better. The longer the delay will be possible the influence of outside culture and the influence of communication technology tools affect the narrator in telling folklore they master.

\section{c. Functional Structure, Motives, and Themes}

Proop (1967 and 1987) concluded that narrative stories from Russian folktales he studied had the same structure. The structure that he intended was more to the functional structure, meaning in the folklore of the perpetrators and their characteristics can change, but the actions 
and functions are the same, do not change. Therefore, Proop views sujzet as a theme not a plot as understood by formalists, because the motives form the theme.

The functional structure of folktale legend of the rebellious Minangkabau boys in West Sumatra who were rebellious to their mother forms the theme of the story. The theme as well as the main message formed by the functional structure of the legend of the Minangkabau boys in West Sumatra who were disobedient to their mother was never to disobey the mother because the consequences were very bad for both the cured and for the cursors themselves. In reverse, listeners to the legendary story of the legend folktale of the Minangkabau boys in West Sumatra who were rebellious to their mother asked not to imitate the characters of the storytellers, especially those related to the behavior and motives of the perpetrators of disobedience and cursing. The motives of the perpetrators of disobedience and condemnation are conveyed not to be imitated and obeyed, but rather to be rejected. In relation to the research conducted by Greimas, this type of storytelling is referred to as the story of the myth of freedom.

The motives of the offender relating to the events of iniquity, condemnation, and the consequences of condemnation are the main themes. Beyond the main theme, the motives of the perpetrators as well as themes and side messages (themes and minor messages) are in the form of exemplary. The motives of the perpetrators of disobedience and condemners before the rebellion occur are the themes and important side messages of legendary folklore, such as being responsive and diligent, resilient trying, like working hard, disciplined, frugal, fast in making decisions, always wanting to be the best in everything, protect, love to guide and advise, and pray for good things for others. This theme and side message, in relation to Greimas' study, is referred to as the story of the myth of concern.

\section{Conclusion}

The folklore of the legend of the son of the Minangkabau in West Sumatra who was rebellious to his mother contained values, a philosophy of life, a description of attitudes and behavior, as well as what the Minangkabau thought. Thus, the folklore of the legend of the Minangkabau people in West Sumatra is both the knowledge and local wisdom of the Minangkabau people in living their lives. The wisdom values of legendary Minangkabau folklore are valuable intangible cultural heritage. As with other oral traditions, the folklore of Minangkabau legend not only has linguistic pragmatic functions in speaking, but also other broader social functions.

The folktale of the legend of the Minangkabau boys in West Sumatra who were rebellious to their mothers as intangible cultural heritage has social functions as well as a projection system; as a means of ratifying paranata and social institutions; as a means of children's education; and as a means of forcing and supervising community norms to always be obeyed. The folklore of legend of the Minangkabau boy in West Sumatra who was rebellious to his mother was a communication tool in terms of community control (social control) which was concrete to criticize someone or a group that had violated the norms of society. Reproach someone by using folklore is easier to accept and more targeted than direct reproach. This is because folklore is not impersonal. As stated by Bakar (1981), Siegel (1979) and Sulistyowati (2016), if someone feels insinuated by hearing folklore addressed to him, he cannot be angry with the narrator because he is aware that the folklore he hears is a traditional heritage of the ancestors of his community that must be obeyed. Critics who use folk tales in these circumstances are supported by cultural heritage traditions. In this position, the tradition plays a role, the narrator only applies as the distributor. 


\section{References}

[1] Ahimsa-Putra, H.S. 2006. Strukturalisme Levi Strauss: Mitos dan Karya Sastra. Yogyakarta: Kepel Press

[2] Bachtiar, Harsya W. 1992. "Kreativitas: Usaha Memelihara Kehidupan Budaya" dalam Majalah Analisis Kebudayaan Nomor 01 Volume 1. Jakarta: Depdikbud

[3] Bakar, Jamil, dkk. 1981. Sastra Lisan Minangkabau. Jakarta: Pusat Pembinaan dan Pengembangan Bahasa

[4] Bakar, Jamil, dkk. 1979. Kaba Minangkabau Jilid 1 dan Jilid 2. Jakarta Pusat Pembinaan dan Pengembangan Bahasa

[5] Barthes, Roland. 2003. Mitologi (translate by Christian Ly). Bandung: Dian Aksara Press

[6] Burhanuddin, Erwina. 2009. Kamus Bahasa Minangkabau-Indonesia Balai Bahasa Padang. Jakarta: Pusat Bahasa Depdiknas

[7] Brunvand, Jand Harold. 1973. "Book Review, Journal of American Folklore Vol. 86, p. 197-198” (in Folklor Indonesia by Danandjaja, 1984) Jakarta: Grafiti

[8] Brunvand, Jand Harold. 1979. Folklor Betawi. Jakarta: Pustaka Jaya

[9] Danandjaja, James. 1984. Folklor Indonesia: Ilmu Gosip, Dongeng, Dan Lain-lain. Jakarta: Grafiti Press

[10] Danandjaja, James. 2003. Folklore Amerika: Cermin Multikulturalisme yang Manunggal. Jakarta: Grafiti Press

[11] Djamaris, Edwar, dkk. 1994. Sastra Daerah di Kalimantan Barat, Tengah, dan Timur: Analisis Tema, Amanat, dan Nilai Budaya. Jakarta: Pusat Pembinaan dan Pengembangan Bahasa

[12] Djamaris, Edwar, dkk. 1993. Nilai Budaya dalam Beberapa Karya Sastra Nusantara: Sastra Daerah di Sumatera. Jakarta: Pusat Pembinaan dan Pengembangan Bahasa

[13] Dundes, A. (Ed.) 2005. Folklore: Critical Concept in Literary and Cultural Studies. Vol. I-III . London: Routledge

[14] Goodenough, Ward H. 1981. Culture, Language, and Society. California: Cummings Publishing Company

[15] Greimas, AJ. 1972. "Comparative Mythtology" in Miranda P (Ed.). Mythology. P. 162-170. Harmondsworth:Penguin

[16] Hadi, Wisran. 2002. "Menyikapi Terjadinya Krisis Identitas dalam Masyarakat Minangkabau" Makalah Seminar Internasional "Indonesia in Transition". Padang: Fakultas Sastra Universitas Andalas Padang

[17] Hasanuddin WS. 2015. Ttransformasi dan produksi Sosial Teks Melalui Tanggapan dan Penciptaan Karya Sastra. Bandung: Angkasa

[18] Hasanuddin WS, Emidar, Zulfadhli. 2018. "Categories of Legends Folktale of Minangkabau People's in West Sumatra" in Proceeding of International Conference on Language, Literature, and Education (ICLLE 1) Published by Atlantis Press Anvances in Social Science, Education and Humanities Reseacrh, Volume 263

[19] Hasanuddin WS, Emidar, Zulfadli. 2019. "Cultural Values Legends Folktale of Minangkabau People's in West Sumatra" in Proceeding of seventh International Conference on Languages and Art (ICLA 7) Published by Atlantis Press Anvances in Social Science, Education and Humanities Reseacrh, Volume 301

[20] Irianto, Sulistyowati. 2016. "Masyarakat Adat dan Keindonesiaan" dalam Harian Kompas terbitan hari Jumat 10 Juni 2016 hlm. 7. Jakarta: Kompas

[21] Jassin, HB. 1983. Sastra Indonesia sebagai Warga Sastra Dunia. Jakarta: Gramedia 
[22] Junus, Umar. 1993. Dongeng tentang Cerita. Kuala Lumpur: Dewan Bahasa dan Pustaka

[23] Koentjaraningrat. 2009. Ilmu Antropologi (Edisi Revisi). Jakarta: Rineka Cipta

[24] Koentjaraningrat. 1977. Metode-metode Penelitian Masyarakat. Jakarta: Gramedia

[25] Navis, A.A. 2002. "Perkisaran Orientasi Masyarakat Minangkabau dari Masa ke Masa" Makalah Seminar Internasional "Indonesia in Transition". Padang: Fakultas Sastra Universitas Andalas

[26] Navis, A.A. 1984. Alam Terkembang Jadi Guru: Adat dan Kebudayaan Minangkabau. Jakarta: Grafiti Press

[27] Proop, Vladimir. 1967. Morphology of the Folktales. Bloomington:Indiana University Press

[28] Proop, Vladimir. 1984. Theory and History of Folklore. Minneapolis: University of minnesota Press

[29] Pudentia, MPSS. 2010. "The Revitalization of Makyong in the Malay Word" Jurnal Wacana XII (1), hlm. 1

[30] Rusyana, Yus. 2000. Prosa Tradisional: Pengertian, Klasifikasi, dan Teks. Jakarta: Pusat Bahasa Departemen Pendidikan Nasional

[31] Sims, M.C. and Martine, S. 2011. Living Folklore: An Introduction to the Study of People and Their Traditions. Logan Utah: Utah State University Press

[32] Scholes, Robert. 1974. Structuralism in Lierature. New Haven: Yale University Press

[33] Sedyawati, Edi. 2007. Keindonesiaan dalam Budaya. Jakarta: Wedatama Widya Sastra

[34] Siegel, James. 1979. Shadow and Sound: The Historical Thought of a Sumatran People. Chicago: University of Chicago Press.

[35] Teeuw, A. 1984. Sastra dan Ilmu Sastra: Pengantar Teori Sastra. Jakarta: Pustaka Jaya 